\title{
Induction of Aquaporin-1 mRNA following Cardiopulmonary Bypass and Reperfusion
}

\author{
Sarah Tabbutt, ${ }^{1,3}$ David P. Nelson, ${ }^{3}$ Nina Tsai, ${ }^{4}$ Takuya Miura, ${ }^{2}$ \\ Paul R. Hickey, ${ }^{3}$ John E. Mayer, ${ }^{2}$ and Ellis J. Neufeld ${ }^{4}$ \\ Departments of ${ }^{1}$ Cardiology, ${ }^{2}$ Cardiac Surgery, and ${ }^{3}$ Anesthesia, and \\ ${ }^{4}$ Division of Hematology, Children's Hospital, Dana Farber Cancer \\ Institute, and Harvard Medical School, Boston, Massachusetts, U.S.A.
}

\begin{abstract}
Background: Cardiopulmonary bypass (CPB) and hypothermic circulatory arrest (HCA) are important components of congenital cardiac surgery. Ischemia/reperfusion injury and inflammatory cascade activation result in endothelial damage and vascular leak, which are clinically manifested as pulmonary edema and low cardiac output postoperatively. Newborns are particularly susceptible. Subtraction cloning is a useful method of isolating induced genes and can be applied to CPB/HCA.

Materials and Methods: We used a newborn lamb model replicating infant $\mathrm{CPB}$ with $\mathrm{HCA}$ to obtain tissues during various periods of reperfusion. We utilized subtraction cloning to identify mRNA induced in lung following CPB/HCA and reperfusion. Ribonuclease protection was used to quantify mRNA levels.

Results: We isolated a cDNA encoding ovine aquaporin- 1 in a subtracted cDNA screen comparing control

lung with lung exposed to $\mathrm{CPB} / \mathrm{HCA}$ and reperfusion. Aquaporin-1 mRNA levels increased 3-fold in lung ( $p=$ .006) exposed to CPB/HCA and $6 \mathrm{hr}$ of reperfusion. No induction was observed immediately following bypass or after $3 \mathrm{hr}$ of reperfusion. We found no significant induction of aquaporin-1 mRNA following bypass, arrest, and reperfusion in other tissues surveyed, including ventricle, atrium, skeletal muscle, kidney, brain, and liver.

Conclusions: Our finding that aquaporin-1 mRNA is reproducibly induced in lung following CPB/HCA with 6 hr of reperfusion suggests an important role for the water channel in the setting of pulmonary edema. Induction of Aquaporin-1 is late compared with other inflammatory mediators (ICAM-1, E-selectin, IL-8). Further studies are needed to determine if aquaporin-1 contributes to the disease process or if it is part of the recovery phase.
\end{abstract}

\section{INTRODUCTION}

Cardiopulmonary bypass (CPB) and hypothermic circulatory arrest (HCA), which are support techniques for pediatric cardiac surgery, invariably result in vascular injury and inflammatory activation, due in part to ischemia and reperfu-

Address correspondence and reprint requests to: Dr. Ellis J. Neufeld, Division of Hematology, Children's Hospital, Enders 720, 300 Longwood Ave., Boston, MA 02115 , U.S.A. Phone: (617) 355-8183; Fax: (617) 734-6791; e-mail: neufeld@Al.tch.harvard.edu

David P. Nelson's present address is Division of Pediatric Cardiology, Children's Hospital Medical Center, University of Cincinnati School of Medicine, Cincinnati, OH 45229 ,

U.S.A. Takuya Miura's present address is Department of Cardiovascular Surgery, Osaka Medical Center and Research Institute for Maternal and Child Health, Osaka, Japan. sion. Clinically, this translates to postoperative morbidity, including pulmonary edema, a transient low cardiac output state, and occasionally, profound capillary leakage. Identification of the inflammatory mediators induced by $\mathrm{CPB} / \mathrm{HCA}$ is necessary to understand the mechanism of the associated vascular injury.

We have previously shown that genes for proinflammatory adhesion molecules ICAM-1 and E-selectin, as well as the potent neutrophil chemoattractant interleukin-8 (IL-8), are induced immediately following CPB in atrium and skeletal muscle in humans $(1,2)$. Using a lamb model of bypass with circulatory arrest, we can obtain several tissues under varying conditions of bypass and varying times of reperfusion. We used subtraction cloning techniques to learn 
which genes might contribute to pulmonary vascular injury with bypass, circulatory arrest, and reperfusion. In a preliminary screening of genes induced in lung, we have identified the ovine homolog of a known water channel protein, aquaporin 1 (AQPl).

Other studies have employed subtraction techniques to demonstrate that major intrinsic protein (a member of the family of aquaporins) is a delayed early response gene following growth factor stimulation of mouse fibroblast cells (3) and that AQP1 expression is lost during repeated passage of aortic vascular smooth muscle cells in culture (4).

AQP1 (initially named CHIP 28) was first identified in erythrocytes and renal proximal tubules $(5,6)$. It belongs to a family of at least five highly conserved membrane water channels, each with characteristic tissue distribution and physiology. AQP1 is a homotetramer of $30 \mathrm{kD}$ subunits which act as functionally independent transmembrane water channels that are sensitive to inhibition by mercury salts (7-10). In rat tissue surveys, AQP1 is found in several epithelia: in ocular ciliary bodies and cornea, choroid plexus, hepatic bile ducts (11), and descending thin limbs of the loop of Henle in the kidney (12). AQP1 has also been localized by immunohistochemical techniques to endothelium of cardiac and skeletal muscle capillaries, and to peribronchiolar and perialveolar capillaries in the lung (11). There are no previous reports of the in vivo impact of vascular injury on the expression of AQP1 or other aquaporins. We have found significant elevation of AQP1 mRNA at $6 \mathrm{hr}$ of reperfusion after cardiopulmonary bypass with circulatory arrest. We propose that this water channel gene may participate in pulmonary vascular leakage or response to injury following cardiopulmonary bypass.

\section{MATERIALS AND METHODS}

\section{Cardiopulmonary Bypass with Hypothermic Circulatory Arrest}

All animals were treated in compliance with the "Principles of Laboratory Animal Care" formulated by the National Society for Medical Research and the "Guide for the Care and Use of Laboratory Animals" (13). The experimental protocol was approved by the Animal Care and Use Committee at Children's Hospital, Boston, MA.

Neonatal lambs (age 2-7 days) were anesthetized with intramuscular ketamine $(40 \mathrm{mg} /$ $\mathrm{kg}$, followed by $0.5 \mathrm{mg} / \mathrm{kg} / \mathrm{hr}$ continuous infusion) and pancuronium bromide $(0.3 \mathrm{mg} / \mathrm{kg})$, and mechanically ventilated with $100 \%$ oxygen. Femoral artery access was obtained for pressure measurements and arterial blood sampling. An electromagnetic flow probe (Nihon, Kodon, Tokyo, Japan) was placed around the main pulmonary artery for cardiac output measurements. A left atrial sheath $(5 \mathrm{Fr})$ and pulmonary artery catheter $(5 \mathrm{Fr})$ were placed for pressure measurements. Baseline cardiac output, pressure measurements, and arterial blood gases were obtained. After systemic heparinization, a pressure transducer $(5 \mathrm{Fr}$ ) was placed in the left ventricular apex. A right femoral artery cannula $(8 \mathrm{Fr})$ and a right atrial cannula (24 Fr) were used for cardiopulmonary bypass.

The bypass circuit consisted of a roller pump and membrane oxygenator (VPCML, Cobe). The pump prime $\left(37^{\circ} \mathrm{C}\right)$ was 800 cc of Normosol and $600 \mathrm{cc}$ of homologous, heparinized whole blood from adult sheep, to achieve a hematocrit of $20 \%$. The bypass pump flow was $150 \mathrm{cc} / \mathrm{kg} / \mathrm{min}$. Phentolamine $(0.2 \mathrm{mg} / \mathrm{kg})$ was given prior to cooling and rewarming. After $30 \mathrm{~min}$ of bypass and cooling to $15^{\circ} \mathrm{C}$, a 2 -hr period of hypothermic circulatory arrest was followed by reinitiating bypass and rewarming to $35^{\circ} \mathrm{C}$ over $30 \mathrm{~min}$ (Fig. 1). Sodium bicarbonate (10 mEq) and defibrillation were administered as needed. Cardiac output, pressures, and arterial blood gases were recorded hourly. The lambs were a median weight of $4.9 \mathrm{~kg}$ (range $2.6-6 \mathrm{~kg}$ ).

\section{Tissue Collection}

Animals who had undergone $\mathrm{CPB} / \mathrm{HCA}$ were rewarmed and sacrificed after 0,3 , or $6 \mathrm{hr}$ of reperfusion. Control animals underwent anesthesia and sternotomy only, at room temperature, and were sacrificed after 20 or $260 \mathrm{~min}$. There were 1-3 animals per condition. Organs were harvested immediately and dissected tissue samples (approximately $5 \times 5 \times 10 \mathrm{~mm}$ ) were placed directly in polypropylene tubes on dry ice. Longterm storage was at $-80^{\circ} \mathrm{C}$.

\section{RNA Extraction}

Tissue samples were made brittle in liquid nitrogen, broken into small pieces with a hammer, and transferred frozen to RNAzol-B (Cinna/Biotecx, Friendswood, TX) and immediately homogenized (Ultra-turrax T25, Janke $\delta$ Kunkel, IKA, Germany). RNA was isolated by acid guani- 


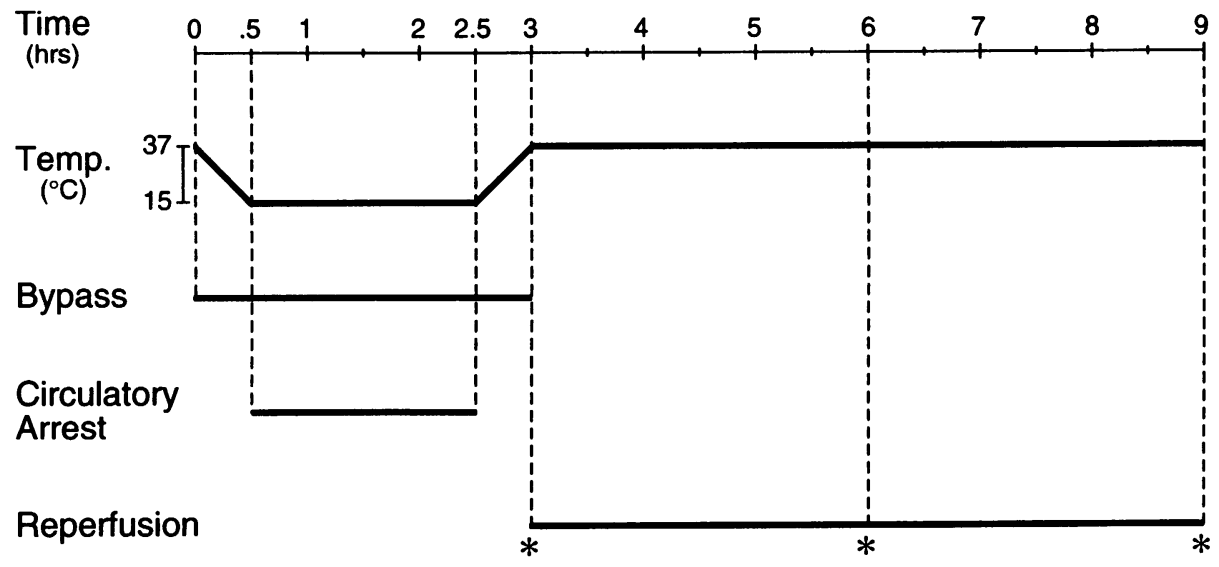

FIG. 1. Experimental time scheme of cardiopulmonary bypass in lambs

Lambs underwent cooling to $15^{\circ} \mathrm{C}$ for $30 \mathrm{~min}$ on bypass prior to $2 \mathrm{hr}$ of circulatory arrest. Lambs were rewarmed to $37^{\circ} \mathrm{C}$ for $30 \mathrm{~min}$ on bypass before reperfusion. Animals were sacrificed after bypass and rewarming $\left({ }^{*}\right)$ at 0,3 , or $6 \mathrm{hr}$ of reperfusion.

dinium-thiocyanate-phenol-chloroform extraction (14). Poly $\mathrm{A}^{+}$RNA was isolated by hybridization with Oligo-dT-linked cellulose (Oligo-dT mRNA Kit, Qiagen, Inc., Chatsworth, CA). RNA was quantitated by spectrophotometry and stored at $-80^{\circ} \mathrm{C}$.

\section{Sheep Lung Post-CPB cDNA Library}

A cDNA library in $\lambda$ ZAPII was constructed from poly $\mathrm{A}^{+}$RNA isolated from neonatal lamb lung tissue harvested after $\mathrm{CPB} / \mathrm{HCA}$ and $3 \mathrm{hr}$ of reperfusion (Clontech Laboratories, Palo Alto, CA). Mixed oligo-dT and random primers were used for first-strand cDNA synthesis. The library contained $1.8 \times 10^{6}$ recombinants, with an average insert size of 1.5 kilobases.

\section{Subtraction Hybridization}

First-strand $\mathrm{CDNA}_{\mathrm{CPB}}$ was generated by reverse transcription of $1 \mu \mathrm{g}$ of oligo-dT-selected RNA isolated from lamb lung after CPB/HCA and $6 \mathrm{hr}$ of reperfusion, by incubating with oligo-dT primer and reverse transcriptase (Subtractor Kit, Invitrogen Corp., San Diego, CA). First-strand $\mathrm{CDNA}_{\mathrm{CPB}}$ was isolated and used as the "tester" population. mRNA CONTROL $_{\text {from lamb lung har- }}$ vested after 20 min of anesthesia only was used as a "driver" population. mRNA CONTROL $_{\text {was bio- }}$ tinylated by incubating with photobiotinacetate under a 300 watt light bulb. A large excess of $10 \mu \mathrm{g}$ of "driver" mRNA CONTROL was hybridized with the "tester" cDNA ${ }_{\mathrm{CPB}}$ for $48 \mathrm{hr}$. After treatment with streptavidin, the biotin:mRNA $\mathrm{CONTROL}_{\mathrm{C}}: \mathrm{CDNA}_{\mathrm{CPB}}$ duplexes were removed by phenol-chloroform extraction, leaving the subtracted, first-strand CDNA $_{\text {CPB-CONTROL; }}$ this represented mRNAs induced in lung during $\mathrm{CPB} / \mathrm{HCA}$ and reperfusion.

\section{Isolation of Subtracted cDNA}

A ${ }^{32} \mathrm{P}$-labeled subtraction probe was generated from the subtracted, first-strand $\mathrm{CDNA}_{\mathrm{CPB}-\mathrm{CONTROL}}$ using random primers and Klenow DNA polymerase (Boehringer-Mannheim, Indianapolis, IN) (15) in a reaction containing $50 \mu \mathrm{Ci}\left[\alpha^{32} \mathrm{P}\right] \mathrm{dCTP}$ (Amersham, Arlington Heights, IL). The sheep lung post-CPB cDNA library described above was plated sparsely (1000 phage per $150-\mathrm{mm}$ plate) to allow isolation of single-phage plaques. Nitrocellulose filter lifts were performed in triplicate. Two lifts were screened with the ${ }^{32} \mathrm{P}$-labeled subtraction probe. One lift was screened with ovine actin cDNA to identify and discard this common cDNA. Remaining nonactin clones on duplicate filters were selected with a toothpick and amplified in host XLl-blue. Phagemids were excised with helper phage as recommended by the manufacturer (Strategene, La Jolla, CA). Inserts were sequenced by the Children's Hospital sequencing facility using a PRISM instrument (ABI, Foster City, CA).

\section{Synthesis of AQP1 Riboprobes}

cDNA templates of ovine AQPI and nonmuscle actin were chosen of different lengths to allow 


\begin{tabular}{|c|c|c|}
\hline Ovine $A Q P 1$ & 16 & $\begin{array}{l}\text { MASEFKKKLFWRAVVAEFLAMI LFI I IS IGSALGF HYPIKSNQTTGAVQD } \\
\text { MASEFKKKLFWRAVVAEFLAMILFIFISIGSALGFHYPIKSNQTTGAVQD }\end{array}$ \\
\hline Bovine $A Q P 1$ & 1 & MASEFKKKLFWRAVVAEFLAMILFIFISIGSALGFHYPIKSNQTTGAVQD \\
\hline Dvine & 66 & ILNPAVTLGLLLSC \\
\hline & & AFGLSIATLAOSVGH ISGAHLNPAVTL \\
\hline
\end{tabular}

Ovine AQP1 16 MASEFKKKLFWRAVVAEFLAMILFIFISIGSALGFHYPIKSNQT MASEFKKKLFWRAVVAEFLA LF+FISIGSALGF YP+ +NQT

Human AQP1 1 MASEFKKKLFWRAVVAEFLATTLFVFISIGSALGFKYPVGNNQT

59

44

FIG. 2. Amino acid sequence homology of the $5^{\prime}$ end of the subtraction clone from ovine lung, with bovine and human AQP1

This sequence homology was obtained from a BLAST search of the GenBank database. Bold amino acid symbol, identical sequence; + , conservative amino acid substitution.

multiplex RNAse protection analysis in a single sample. A 125-bp fragment of AQP1 cDNA from within the coding region was amplified by polymerase chain reaction with artificial restriction sites placed in the primers to enable cloning into the BamHl and EcoRI sites of the plasmid vector, pBluescript II KS (Stratagene). Transcription from $0.5 \mu \mathrm{g}$ linearized AQPl template produced a full-length, 168-nucleotide (nt) probe with a 125-nt protected sequence. Nonmuscle actin cDNA, which was transcribed from $0.5 \mu \mathrm{g}$ plasmid vector pBluescript II $\mathrm{KS}$ and linearized with Accl, had a full-length, 136-nt probe with a 63-nt protected sequence. Transcription reactions contained $100 \mu \mathrm{Ci}\left[\alpha^{32} \mathrm{P}\right] \mathrm{CTP}$ (Amersham). T7 and T3 RNA polymerase (Promega, Madison, WI) were used for antisense and sense transcription, respectively.

\section{Ribonuclease (RNAse) Protection Assay}

The RNAse protection assay was modified from Kilbridge et al. as follows (2). Total RNA (30 $\mu \mathrm{g})$ extracted and purified from lamb tissue was hybridized with $300,000 \mathrm{cpm} A Q P 1$ riboprobe and $50,000 \mathrm{cpm}$ nonmuscle actin riboprobe. tRNA (30 $\mu \mathrm{g})$ and sense riboprobes were run as negative controls. After overnight hybridization $\left(37^{\circ} \mathrm{C}\right)$, single-stranded RNA was digested $\left(37^{\circ} \mathrm{C}\right.$, $90 \mu \mathrm{min}$ ) with $80 \mu \mathrm{g} / \mathrm{ml}$ RNase A (Boehringer) and $4 \mathrm{U} / \mathrm{ml}$ RNase $\mathrm{Tl}$ (Boehringer). Samples were analyzed on a 5\% acrylamide-urea sequencing gel.

\section{Data Analysis}

Protected bands were quantified by PhosphorImager analysis and ImageQuant software (Molecular Dynamics, Sunnyvale, CA). After subtracting background levels from tRNA negative control lane, AQP1 signal was normalized to its internal nonmuscle actin control, [AQPI-tRNA]/ [actin-tRNA]. Different tissue samples from the same experimental condition were combined $(n=2-5)$ and conditions compared using a Student's $t$-test assuming unequal variances. All experiments were confirmed in duplicate.

\section{RESULTS}

\section{Subtraction Cloning of Genes Induced during CPB/HCA and Reperfusion in Lung}

mRNA was isolated from lung tissue of a neonatal lamb subjected to $\mathrm{CPB} / \mathrm{HCA}$ followed by reperfusion, and from a control lamb with anesthesia and sternotomy only. Transcribed cDNA from lung after $\mathrm{CPB} / \mathrm{HCA}$ and reperfusion was hybridized with excess biotinylated mRNA from control lambs and the mRNA-cDNA complexes were removed, leaving subtracted cDNA that 
TABLE 1. Hemodynamic parameters of neonatal lambs at baseline and following CPB/HCA

\begin{tabular}{|c|c|c|c|c|c|}
\hline & \multicolumn{2}{|c|}{ Baseline } & \multicolumn{2}{|c|}{ After CPB/HCA } & \multirow{2}{*}{$\begin{array}{c}p \\
\text { Value }\end{array}$} \\
\hline & Mean & Standard Error & Mean & Standard Error & \\
\hline Blood pressure (mm $\mathrm{Hg}$ ) & 67.5 & 3.5 & 65.3 & 2.3 & .60 \\
\hline PA pressure (mm Hg) & 15.6 & 1.2 & 18.8 & 1.0 & .05 \\
\hline LA pressure (mm $\mathrm{Hg}$ ) & 2.8 & .43 & 3.1 & .22 & .53 \\
\hline CVP (mm Hg) & 3.1 & .31 & 4.0 & .33 & .07 \\
\hline Cardiac output (l/min) & .98 & .16 & 1.2 & .14 & .32 \\
\hline Heart rate (bpm) & 192 & 11 & 226 & 4 & .01 \\
\hline Temperature $\left({ }^{\circ} \mathrm{C}\right)$ & 36.0 & .46 & 36.1 & .18 & .79 \\
\hline Hematocrit (\%) & 30.9 & 1.3 & 26.2 & .38 & .01 \\
\hline $\mathrm{PO}_{2}$ & 399 & 39 & 320 & 28 & .12 \\
\hline $\mathrm{PCO}_{2}$ & 34.1 & 1.5 & 36.1 & 1.5 & .37 \\
\hline $\mathrm{pH}$ & 7.38 & .02 & 7.43 & .02 & .08 \\
\hline
\end{tabular}

represented genes induced in lung with $\mathrm{CPB} /$ HCA and reperfusion. This subtracted cDNA was labeled and used to probe a post-CPB/HCA CDNA library from lung. In this pilot scale screen, 20 cDNAs were isolated. One scale screen encoded a cDNA fragment highly homologous to human AQP1. This fragment $(\sim 700 \mathrm{bp})$ was ${ }^{32} \mathrm{P}$-labeled and used to rescreen the post-CPB lung CDNA library. Purification and sequencing of labeled clones confirmed isolation of the full-length cDNA encoding ovine AQP1. A BLAST search (16) of the GenBank database with the 5' end of ovine AQP1 cDNA revealed $98 \%$ amino acid homology with bovine AQPl (CHIP 29) and $84 \%$ homology with human AQP1 (CHIP 28) (Fig. 2).

\section{Physiologic Parameters of Neonatal Lambs}

There was no significant difference in mean blood pressure, pulmonary artery pressure, left atrial pressure, central venous pressure, cardiac output, temperature, $\mathrm{PO}_{2}, \mathrm{PCO}_{2}$, or $\mathrm{pH}$ obtained at baseline compared with hourly measurements obtained from lambs during reperfusion following $\mathrm{CPB} / \mathrm{HCA}$ at $15^{\circ} \mathrm{C}$ or $20^{\circ} \mathrm{C}$ (Table 1). There was a statistically significant increase in heart rate, and a decrease in hematocrit following
CPB/HCA, compared with baseline levels. However, all values were within physiological range.

\section{Tissue Expression of AQPI mRNA}

We examined the tissue distribution of AQP1 mRNA in neonatal lambs. Quantitative comparison of AQP1 mRNA levels in tissues pre- and post-CPB/HCA (at $15^{\circ} \mathrm{C}$ ), were performed. RNA was isolated under three conditions: (1) control: 20 min sternotomy only; (2) following CPB/HCA with 30 min rewarming and no additional reperfusion; and (3) after CPB/HCA followed by $6 \mathrm{hr}$ of reperfusion. Using the RNAse protection assay, we examined AQP1 mRNA levels in lung, ventricle, atrium, brain, liver, kidney, and skeletal muscle (Fig. 3A). AQP1 signals were normalized to an internal nonmuscle actin control. Results are quantified in Fig. 3B. AQP1 mRNA was undetectable by the sensitive RNAse protection assay in brain and liver. There was minimal expression in atrium and skeletal muscle, and easily detectable levels in ventricle, kidney, and lung. The lung demonstrated a significant change during the time course of CPB/HCA, which is further described in the following section. 


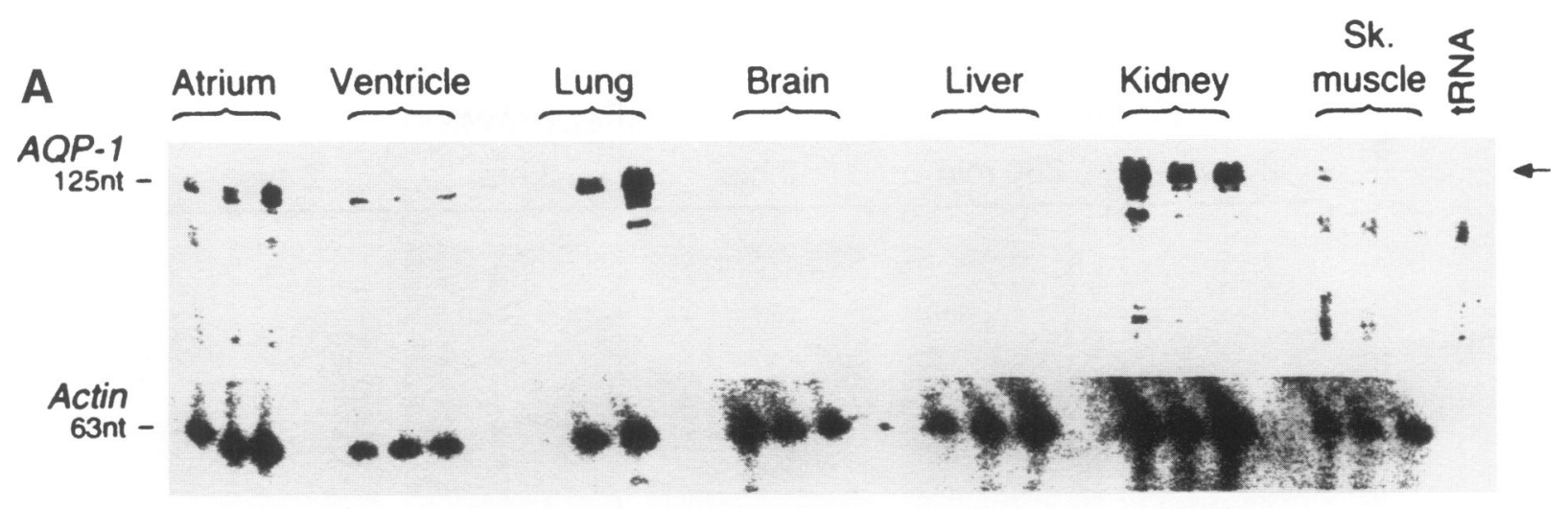

B

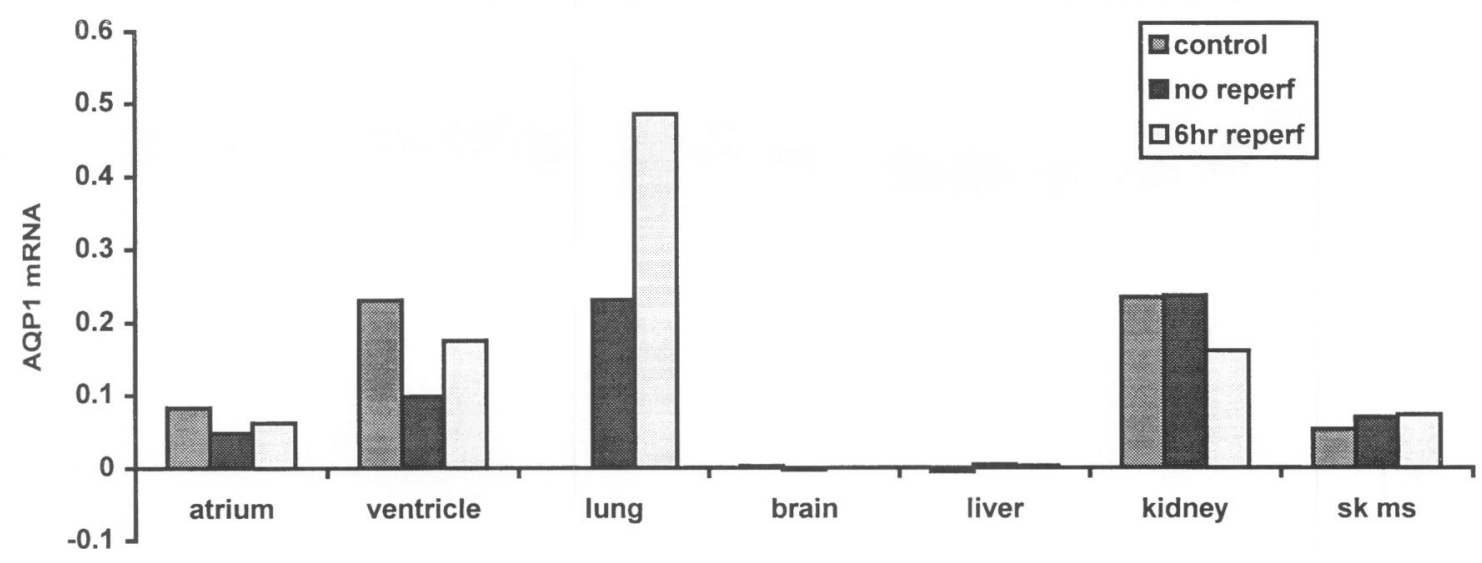

FIG. 3. AQPI mRNA levels in lamb tissues before and after CPB with $\mathrm{HCA}$ at $15^{\circ} \mathrm{C}$

(A) Autoradiograph of RNAse protection assay. For each organ: left, 20 min sternotomy only; middle, CPB/HCA, no reperfusion; right, $6 \mathrm{hr}$ of reperfusion following CPB/HCA. The expected AQP1-protected band is 125 nucleotides (nt) and the expected actin-protected band is $63 \mathrm{nt}$. Total RNA was lost from the lung control sample.

(B) Quantitation of AQPl mRNA levels obtained from PhosphorImager analysis of the sequencing gel in A. Background was determined by tRNA control. AQPl was normalized to the internal actin control, [AQP1-tRNA]/ [actin-tRNA]. Negative numbers represent AQPI signals weaker than background tRNA. Control, 20 min sternotomy only; no reperf, $\mathrm{CPB} / \mathrm{HCA}$ without reperfusion; $6 \mathrm{hr}$ reperf, $6 \mathrm{hr}$ of reperfusion following CPB/HCA. Lung control data were not obtained in this experiment.

\section{Induction of AQP1 mRNA during CPB/HCA and Reperfusion}

Induction of AQP1 mRNA during cardiopulmonary bypass ( $3 \mathrm{hr}$ ) with hypothermic circulatory arrest $\left(2 \mathrm{hr}\right.$ at $\left.15^{\circ} \mathrm{C}\right)$ followed by reperfusion (up to $6 \mathrm{hr}$ at $37^{\circ} \mathrm{C}$ ) was determined by RNAse protection assay of parallel samples from the same tissue type but harvested under different experimental conditions (Fig. 1). Samples included: 20 and 260 min, sternotomy only, controls; and $\mathrm{CPB} / \mathrm{HCA}$ followed by 0,3 , or $6 \mathrm{hr}$ of reperfusion $\left(37^{\circ} \mathrm{C}\right)$. Two to three animals per condition were evaluated and 1 to 4 separate tissue samples per animal were analyzed. All AQP1 mRNA levels were normalized to an internal nonmuscle actin control and background was subtracted from tRNA negative control.
The lung demonstrated a reproducible 3 -fold induction in AQPI mRNA after CPB/HCA followed by $6 \mathrm{hr}$ of reperfusion $(3.38 \pm .28 \mathrm{com}-$ pared with 20 min control, $1.0 \pm .15, p$ value, .005) (Fig. 4). This induction was not seen immediately following CPB $(1.74 \pm .58)$ nor after 3 $\mathrm{hr}$ of reperfusion (1.24 \pm .05$)$. There was a significant increase in AQPl mRNA between $3 \mathrm{hr}$ of reperfusion and $6 \mathrm{hr}$ of reperfusion ( $p$ value, $.016)$.

Ventricle AQPI mRNA levels were not induced in neonatal lambs during $\mathrm{CPB} / \mathrm{HCA}$ or during $6 \mathrm{hr}$ of reperfusion. AQPI mRNA levels normalized to internal actin control were not significantly different between the 20 -min control $(0.203 ; \pm 0.037)$ and $\mathrm{CPB} / \mathrm{HCA}$ with no reperfusion $(0.198 ; \pm 0.023, p$ value, .90$), \mathrm{CPB} /$ 

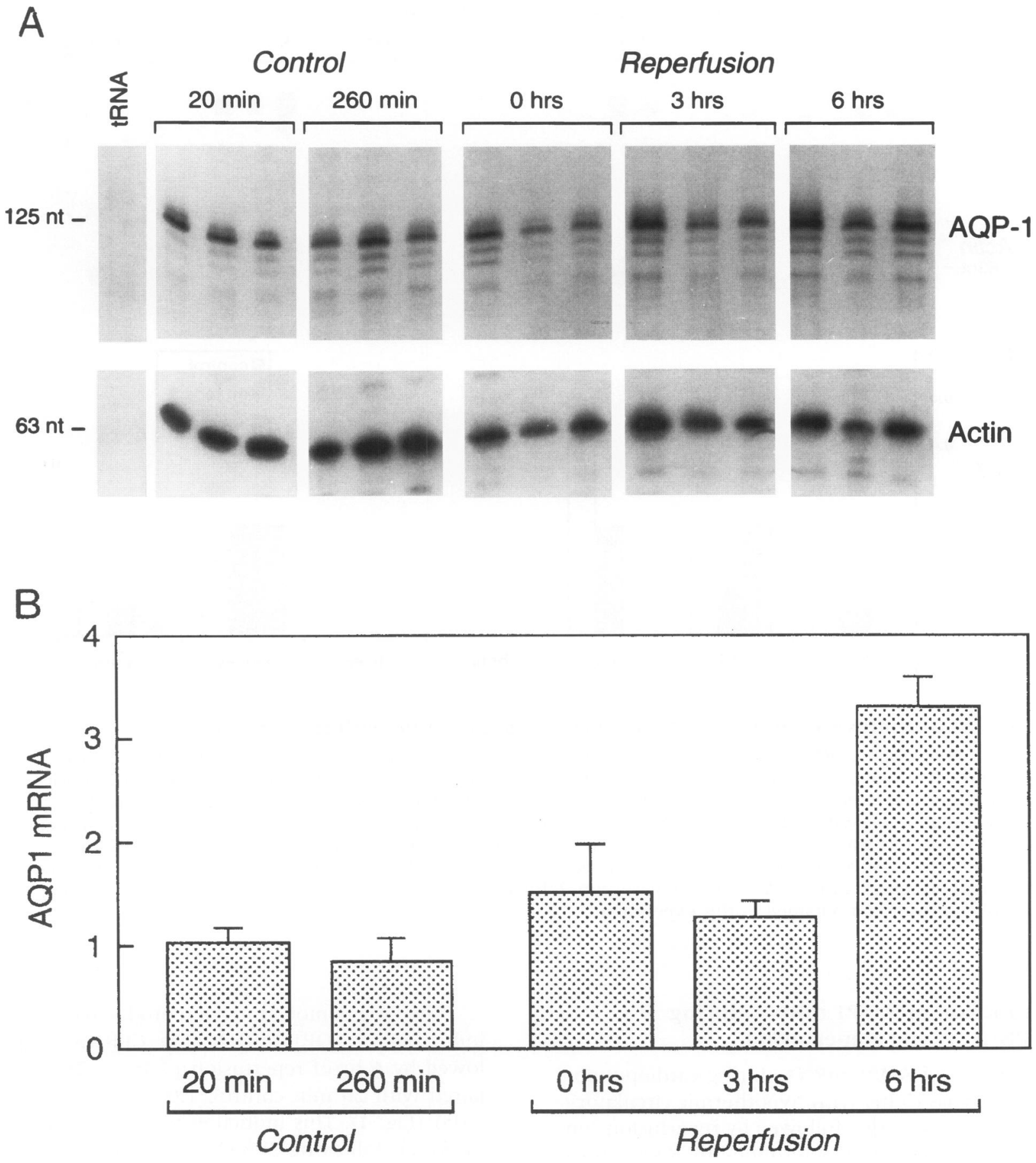

FIG. 4. AQP1 mRNA in lung before and after CPB/HCA followed by reperfusion

(A) Autoradiograph of RNase protection assay. Each lane represents a separate tissue specimen; each condition represents 2-3 animals. Control animals underwent sternotomy only for 20 or $260 \mathrm{~min}$. Reperfusion animals underwent $\mathrm{CPB} / \mathrm{HCA}\left(2 \mathrm{hr}\right.$ of circulatory arrest at $\left.15^{\circ} \mathrm{C}\right)$ followed by 0,3 , or $6 \mathrm{hr}$ of reperfusion at $37^{\circ} \mathrm{C}$. The nonmuscle actin-protected band is 63 nucleotides (nt). Three fragments of AQP1 mRNA are seen below the expected $125 \mathrm{nt}$ AQP1-protected band. (B) Quantitation of AQP1 mRNA levels obtained from PhosphorImager analysis of the sequencing gel in A. Background was determined by tRNA control. AQP1 was normalized to the internal actin control, [AQP1-tRNA]/[actin-tRNA]. All samples were then normalized to a mean of 1 for the 20-min control samples. Comparative values of AQP1 normalized to actin were similar, regardless of whether the single 125-nt AQP1 band or all 4 bands were quantitated. 
HCA with $3 \mathrm{hr}$ of reperfusion $(0.157 ; \pm 0.007$, $p$ value, .27), or CPB/HCA with $6 \mathrm{hr}$ of reperfusion $(0.285 ; \pm 0.035, p$ value, .21$)$.

There was considerable variance in kidney AQP1 mRNA levels without a specific trend during $\mathrm{CPB} / \mathrm{HCA}$ and reperfusion. This variability most likely reflects the random harvesting of tissue from within the kidney with samples containing various amounts of proximal tubules and thin descending limbs where AQP1 is known to be localized. More specific harvesting in the future would be required to obtain comparable samples and to determine if AQP1 mRNA is induced.

Because AQP1 mRNA levels are known to increase in rat lung $12 \mathrm{hr}$ following corticosteroid administration (17), it is possible that the induction we observed in lamb lung was a result of an endogenous stress response to anesthesia, surgery, bypass, and/or hypothermia. We compared AQP1 mRNA levels in lung from a lamb treated with $30 \mathrm{mg} / \mathrm{kg}$ methylprednisolone, followed by $260 \mathrm{~min}$ of anesthesia, to control animals with $260 \mathrm{~min}$ of anesthesia alone. No difference was observed (steroid lamb $70 \%$, and 260 min control lamb $60 \%$, of 20 min control AQPl mRNA levels).

\section{DISCUSSION}

The recent discovery of a highly conserved family of water channels, aquaporins, has significantly increased understanding of rapid trans membrane water fluxes. A majority of research has focused on the role of aquaporins in the kidney, where mutations in AQP2 cause nephrogenic diabetes insipidus (18-20). High-resolution immunoelectron microscopy studies have demonstrated reversible migration of AQP2 from intracellular vesicles to the apical plasma membrane in response to vasopressin (21). AQP1 is expressed at the cell surface and is sensitive to inhibition by mercury salts $(7,8,10)$. In studies of sheep lung, Folkesson et al. demonstrated that a mercury-sensitive water channel plays an important role in water permeability across capillary endothelium and into alveolar spaces (22). Using an isolated lung perfused continuously with an iso-osmotic dilute blood solution, they measured the movement of water (determined by dilution of radiolabeled albumin) from the capillaries to the alveolar spaces which contained hypertonic (900 mOsm/l) fluid instilled bronchoscopically. In the control lung, the osmotically induced wa- ter permeability had a $t_{1 / 2}$ of $.85 \mathrm{~min}$. Water permeability in the contralateral lung was reversibly attenuated ( $\left.t_{1 / 2} 2.7 \mathrm{~min}\right)$ by mercury $\left(0.5 \mathrm{mM} \mathrm{HgCl}_{2}\right)$. In addition, in isolated rat alveolar type II epithelial cells, they measured an osmotic water permeability $\left(\mathrm{P}_{\mathrm{f}} 0.015 \pm .002 \mathrm{~cm} /\right.$ sec, $10^{\circ} \mathrm{C}$ ) which is comparable to the water permeability reported in AQP1-rich erythrocytes $\left(\mathrm{P}_{\mathrm{f}}\right.$, $0.02 \mathrm{~cm} / \mathrm{sec}$ ) (23) and in isolated renal tubules $\left(\mathrm{P}_{\mathrm{f}}, 0.007-0.06 \mathrm{~cm} / \mathrm{sec}\right)$ (21). As a known mercury-sensitive water channel, AQP1 may play an important role in water permeability between alveolar spaces and perialveolar capillaries. Additional studies demonstrated a significant induction in AQP1 mRNA and protein expression $(17,24)$ in perinatal rat lung, implying a potential role for AQP1 in lung water clearance at birth. This effect was augmented by corticosteroids, suggesting that under some circumstances, AQP1 induction may be part of an intrinsic stress response (17).

Using subtraction cloning techniques, we isolated full-length ovine AQP1 cDNA from neonatal lamb lung. This ovine cDNA was highly homologous to bovine and human AQP1. In the setting of cardiopulmonary bypass in neonatal lambs, we found that AQP1 mRNA is increased 3 -fold in lung after cardiopulmonary bypass and circulatory arrest $\left(15^{\circ} \mathrm{C}\right)$ followed by $6 \mathrm{hr}$ of reperfusion $\left(37^{\circ} \mathrm{C}\right)$. This increase was not seen after $3 \mathrm{hr}$ of reperfusion, nor was it seen to a significant degree in the other tissues. Substantial increases in AQP1 mRNA levels in lung have been demonstrated during the perinatal period in rats as a function of age $(17,24)$. In our experiments, mean lamb age among different conditions was similar (control, mean $=3$ days; no reperfusion, mean $=5$ days; $3 \mathrm{hr}$ reperfusion, mean $=4.5$ days; $6 \mathrm{hr}$ reperfusion mean $=5$ days). Therefore, age was not the sole determinant of increases in AQP1 mRNA levels, but it may have contributed to variation among samples. We demonstrated that high-dose corticosteroids do not result in AQP1 mRNA induction in lung over a 4-hr time course in an anesthetized lamb. Further study would be needed to determine if endogenous stress response hormones contribute to AQP1 induction observed at a later time following $\mathrm{CPB} / \mathrm{HCA}$.

Nieslen et al., studying tissue distribution of AQP1 in rats, demonstrated an abundance of AQP1 in the kidney and erythrocytes, moderate levels in lung, lesser amounts in the heart and liver, and none in the brain (11). In lambs, we found that AQP1 mRNA was essentially unde- 
tectable in brain and liver, minimally expressed in skeletal muscle and atrial muscle, and expressed significantly in ventricle, kidney, and lung.

Identification of AQP1 by differential gene expression after $\mathrm{CPB} / \mathrm{HCA}$ is important and relevant for understanding bypass-related lung injury for two reasons. First, AQP1 mRNA levels are significantly induced by the subtraction conditions (CPB/HCA and $6 \mathrm{hr}$ of reperfusion versus control). Second, increased AQP1 mRNA levels during a period of susceptibility to bypass-related, acute pulmonary edema is functionally consistent with the observation of mercury-sensitive water movement from capillaries to the alveolar space (22) and the observation of induction of AQP1 mRNA and protein expression in rat lung during the perinatal period $(17,24)$. Further studies are needed to document increases in AQP1 protein expression and localization to perialveolar capillary endothelium associated with pulmonary vascular leak.

Induction of AQP1 mRNA in lung following $\mathrm{CPB} / \mathrm{HCA}$ with reperfusion is late compared with induction of inflammatory mediators (ICAM- 1 , E-selectin and interleukin-8) $(1,2)$, which participate in leukocyte recruitment, vascular injury, and associated capillary leak. Other studies imply a role for AQP1 in clearance of lung water $(17,22,24)$. The late induction of AQP1 mRNA in lung may reflect a response to the pulmonary edema that occurs as a result of endothelial damage following $\mathrm{CPB} / \mathrm{HCA}$. Further investigations into the role of AQP1 in the lung could have significant clinical impact on understanding and managing other processes involving pulmonary vascular endothelial or alveolar epithelial damage, such as sepsis, neonatal respiratory distress syndrome, or adult respiratory distress syndrome.

\section{ACKNOWLEDGMENTS}

We thank Eric Wang for rescreening AQP1 cDNA, Marc Schermerhorn for assistance with the lamb experiments, Amy Stagg for help with the RNAse protection of the steroid lamb, and Cristina Tufarelli and Janae Donady for their helpful suggestions. This work was supported by NIH program project grant HL48675 (P.R.H., J.E.M.), an American Heart Association Massachusetts Affiliate Grant-in-Aid (E.J.N.), and an NIDR Training Grant T35 DE07268 (N.T.). E.J.N. is a fellow of the Lucille P. Markey Charitable Trust.

\section{REFERENCES}

1. Burns SA, Newburger JW, Xiao M, Mayer JE, Walsh AZ, Neufeld EJ. (1995) Induction of Interleukin-8 messenger mRNA in heart and skeletal muscle during pediatric cardiopulmonary bypass. Circulation (Suppl. II) 92: II 315-317.

2. Kilbridge PM, Mayer JE, Newburger JW, Hickey PR, Walsh AZ, Neufeld EJ. (1994) Induction of ICAM-1 and E-selectin mRNA in heart and skeletal muscle of pediatric patients undergoing cardiopulmonary bypass. J. Thorac. Cardiovasc. Surg. 107: 1183-1192.

3. Lanahan A, Williams JB, Sanders LK, Nathans D. (1991) Growth factor-induced delayed early response genes. Mol. Cell. Biol. 12: 3919-3929.

4. Shanahan CM, Weissberg PL, Metcalfe JC. (1993) Isolation of gene markers of differentiated and proliferating vascular smooth muscle cells. Circ. Res. 73: 193-204.

5. Denker BM, Smith BL, Kuhajda FP, Agre P. (1988) Identification, purification and partial characterization of a novel $\mathrm{Mr} 28,000$ integral membrane protein from erythrocytes and renal tubules. J. Biol. Chem. 263: 1563415642.

6. Preston GM, Agre P. (1991) Isolation of the cDNA for erythrocyte integral membrane protein of $28 \mathrm{kD}$ : Member of an ancient channel family. Proc. Natl. Acad. Sci. U.S.A. 88: $11110-11114$.

7. Nielsen S, Agre P. (1995) The aquaporin family of water channels in kidney. Kidney Int. 48: 1057-1068.

8. Knepper MA. (1994) The aquaporin family of molecular water channels. Proc. Natl. Acad. Sci. U.S.A. 91: 6255-6258.

9. Moon C, Preston GM, Griffin CA, Jabs EW, Agre P. (1993) The human aquaporin-CHIP gene. J. Biol. Chem. 268: 15772-15778.

10. Preston GM, Jung JS, Guggin WB, Agre P. (1993) The mercury-sensitive residue at cysteine 189 in CHIP 28 water channel. J. Biol. Chem. 268: 17-20.

11. Nielsen S, Smith BL, Christensen EI, Agre P. (1993) Distribution of the aquaporin CHIP in secretory and resorptive epithelia and capillary endothelia. Proc. Natl. Acad. Sci. U.S.A. 90: 7275-7279.

12. Nielsen $S$, Pallone $T$, Smith BL, Christensen EI, Agre P, Maunsbach AB. (1995) Aquaporin-1 water channels in short and long 
loop descending thin limbs and in descending vasa recta in rat kidney. Am. J. Physiol. 268: F1023-F1039.

13. National Institutes of Health. (1985) Guide for the Care and Use of Laboratory Animals. NIH Publication No. 86-23, Bethesda, MD.

14. Chomczynkski P, Sacci N. (1987) Single-step method of RNA isolation by acid guanidinium-thiocyanate-phenol-chloroform extraction. Anal. Biochem. 162: 156-159.

15. Sambrook J, Fritsch EF, Maniatis $\mathrm{T}$ (eds). (1989) Molecular Cloning: A Laboratory Manual, 2nd ed. Cold Spring Harbor Laboratory, Cold Spring Harbor, NY.

16. Altschul SF, Gish W, Miller W, Myers EW, Lipman DJ. (1990) Basic local alignment search tool. J. Mol. Biol. 215: 403-410.

17. King LS, Nielsen S, Agre P. (1996) Aquaporin-1 water channel protein in lung. J. Clin. Invest. 97: 2183-2191.

18. Merendino JJ, Spiegel AM, Crawford JD, $\mathrm{O}^{\prime}$ Carroll AM, Brownstein MJ, Lolait SJ. (1993) Brief report: A mutation in the vasopressin V2 receptor gene in a kindred with $\mathrm{X}$-linked nephrogenic diabetes insipidus. N. Engl. J. Med. 328: 1538-1541.

19. Lolait SJ, O'Carroll AM, McBride OW, Konig M, Morel A, Brownstein MJ. (1992) Cloning and characterization of a vasopressin V2 re-

Communicated by D. Nathan. Accepted June 27, 1997. ceptor and possible link to nephrogenic diabetes insipidus. Nature 357: 336-339.

20. Holtzman EJ, Harris HW, Kolakowski LF, Guay-Woodford LM, Botelho B, Ausiello DA. (1993) Brief report: A molecular defect in the vasopressin V2-receptor gene causing nephrogenic diabetes insipidus. $N$. Engl. J. Med. 328: 1534-1537.

21. Nielsen S, Chou CL, Marples D, Christensen EI, Kishore BK, Knepper MA. (1995) Vasopressin increases water permeability of kidney collecting duct by inducing translocation of aquaporin-CD water channels to plasma membrane. Proc. Natl. Acad. Sci. U.S.A. 92: 1013-1017.

22. Folkesson HG, Matthay MA, Hasegawa $H$, Kheradmand F, Verkman AS. (1994) Transcellular water transport in lung alveolar epithelium through mercury sensitive water channels. Proc. Natl. Acad. Sci. U.S.A. 91: 4970-4974.

23. Macey RI, Farmer REL. (1970) Inhibition of water and solute permeability in human red cells. Biochem. Biophys. Acta 211: 104-106.

24. Umenishi F, Carter EP, Yang B, Oliver B, Matthay MA, Verkman AS. (1996) Sharp increase in rat lung water channel expression in the perinatal period. Am. J. Respir. Cell. Mol. Biol. 15: 673-679. 